\title{
Age-related changes in peripheral hormone concentrations and their relationships with testis size and number of Sertoli and germ cells in yearling beef bulls
}

\author{
A. A. Moura ${ }^{*}$ and B. H. Erickson \\ Department of Animal Science, The University of Tennessee, Knoxville, TN 37969-1071, USA
}

\begin{abstract}
A study was conducted to determine whether basal or GnRH-stimulated concentrations of FSH, LH, testosterone, androstenedione and oestradiol measured from 2 months to 12 months of age were correlated with size and histology of the testes of Angus bulls at 12 months of age. Three blood samples per month were taken from 24 calves at $1.5 \mathrm{~h}$ intervals to establish basal hormone concentrations. On the following day, calves received $0.05 \mu \mathrm{g}$ of $\mathrm{GnRH} \mathrm{kg}{ }^{-1}$ body mass and were bled $1.5 \mathrm{~h}$ and $3.0 \mathrm{~h}$ later. At 12 months of age, bulls were castrated and testes were measured and prepared for histological analysis. Yearling testis diameter was related to GnRH-stimulated testosterone at 3 months $(r=0.48, P<0.05)$. Basal FSH at all ages between 2 months and 12 months was correlated with yearling testis diameter $(r=-0.53, P<0.05$, to $r=-0.74, P<0.01)$. In addition, basal $\mathrm{FSH}$, measured at 2 and 3 months and between 8 and 12 months, was related to number of Sertoli cells per testis $(r=-0.47, P<0.05$, to $r=-0.53, P<0.05)$, number of round spermatids per AI spermatogonium $(r=-0.48, P<0.05$, to $r=-0.60, P<0.01)$ and number of round spermatids per Sertoli cell $(r=-0.50, P<0.05$, to $r=-0.64, P<0.01)$. Similarly, prepubertal concentrations of GnRH-stimulated FSH between 2 months and 12 months of age were correlated with testis diameter $(r=$ non-significant, to $r=-0.71, P<0.01)$ and cell ratios in the seminiferous tubules $(r=$ non-significant, to $r=-0.61, P<0.01$ ). Thus, prepubertal hormone secretion could serve as a meaningful index of the potential sperm-producing capacity of the yearling bull.
\end{abstract}

\section{Introduction}

In bulls, testis size is closely related to daily sperm output $(r=0.80-0.90$; reviewed by Coulter and Foote, 1979) and daily sperm production $(r=0.65-0.72$; Amann and Almquist, 1962; Berndtson et al, 1987a, b; Palasz et al., 1994). Testis size is heritable $\left(h^{2}=0.41\right.$; Lunstra et al., 1988) and correlates with age at puberty $(r=-0.85$; Lunstra et al., 1978), and breeds with greater scrotal circumference have an earlier age at puberty and a higher pregnancy rate in female offsprings $(r=0.90$; Martin et al., 1992). Thus, testis size is a reliable indicator of sperm-producing capacity of bulls and a meaningful aid to improvement of the reproductive performance of the herd.

The Sertoli cell is the only somatic cell present in the seminiferous tubules and it provides morphological, nutritional and hormonal support for the germ cells (Bardin et al., 1994). Sertoli cells proliferate during fetal and neonatal life and, in cattle, become amitotic between 6 weeks and 10 weeks of age (Sharpe, 1994). A decrease in the Sertoli cell population caused by treatment with radiation (Erickson and Blend, 1976) or

*Present address: Departamento de Zootecnia, Universidade Federal do Ceará, Av. Mister Hull, s/n, Caixa Postal 12168, Campus do Pici, Fortaleza, Ceará, Brazil. Email: amoura@ufc.br

Revised manuscript received 24 June 1997. cytosine arabinoside (an antimitotic drug; Orth et al., 1988) leads to reduced testis size in rats, and it is believed that each Sertoli cell can support only a limited number of spermatids (Berndtson et al., 1987a). In addition, the number of Sertoli cells has been shown to account for a significant proportion of the variability in daily sperm production $\left(R^{2}=0.68\right)$ and testis mass $\left(R^{2}=0.56\right)$ among adult dairy bulls (Berndtson et al., 1987a). Thus, the number of Sertoli cells per testis ultimately determines both potential sperm-producing capacity and testis size in bulls.

Age-related changes in testicular development are regulated mainly by the interaction between gonadotrophins and sex steroids (Schanbacher, 1982). Important aspects of Sertoli cell function, such as mitosis, differentiation, synthesis of oestradiol and androgen-binding protein, and secretion of tubular fluid and growth factors, are dependent on FSH and testosterone (reviewed by Bardin et al., 1994). In addition, the phase of growth and subsequent maturation of the Leydig cell that precedes the onset of spermatogenesis is controlled by LH and FSH (Khan et al., 1994) and it is generally accepted that both FSH and testosterone are essential for normal proliferation and differentiation of germ cells (Sharpe, 1994).

Although the development of the hypothalamic-pituitarygonadal axis and the hormonal control of spermatogenesis 
have been studied in bulls and other species, it is still unclear how gonadotrophins and steroids interact before puberty to determine numbers of Sertoli and germ cells and testis size. Thus, a study was conducted to determine whether peripheral concentrations of basal and GnRH-stimulated FSH, LH, testosterone, androstenedione and oestradiol measured in Angus bulls from 2 months to 12 months of age were correlated with testis size and number of Sertoli and germ cells at 12 months.

\section{Materials and Methods}

\section{General procedures}

Twenty-four Angus bulls, born between 6 January and 30 March, were used. Calves were pastured with their dams until weaning ( 8 months), and thereafter kept in feedlots with free access to hay and corn silage. Starting at 2 months and continuing until 12 months of age, all bulls were bled from the jugular vein three times at $1.5 \mathrm{~h}$ intervals to establish basal hormone concentrations. On the following day, bulls received a s.c. injection of $\mathrm{GnRH}$ (des-Gly ${ }^{10}$, [D-Ala $\left.{ }^{6}\right]-G n R H$-ethylamide; Sigma Co., St Louis, MO) and blood samples were taken $1.5 \mathrm{~h}$ and $3.0 \mathrm{~h}$ later. Doses of $\mathrm{GnRH}$ were given based on a ratio of $0.05 \mu \mathrm{g} \mathrm{kg}^{-1}$ body mass. Animals were weighed each month and the diameter of the right testis was measured using a caliper. At the age of 12 months (361 \pm 15 days; $433.3 \pm 6.5 \mathrm{~kg}$ ), all bulls were surgically castrated by a veterinarian using approved animal care practices.

The pattern of sampling after the GnRh challenge was defined after a study conducted in the previous year, in which Angus bulls at 8 months of age were treated with GnRH (0.05 $\mu \mathrm{g} \mathrm{kg}^{-1}$ body mass) and bled $1.5 \mathrm{~h}(n=8), 3.0 \mathrm{~h}(n=8)$ and $4.5 \mathrm{~h}(n=8)$ later.

\section{Histological analysis}

At castration, testes were weighed and measured after removal of the tunica vaginalis and epididymis. Two segments $(4 \mathrm{~mm})$ were taken near the poles of one testis and placed in Bouin's fixative for $24 \mathrm{~h}$, rinsed with water and washed in three changes of $70 \%$ ethanol. The tissue was dehydrated in alcohol, embedded in paraffin wax, sectioned at $5 \mu \mathrm{m}$ and stained with haematoxylin and eosin. One slide from each testicular segment was used.

In cattle, there is uniformity between different regions within the testis (Amann, 1962; Swierstra, 1966). Berndtson et al. (1987a) have estimated that the use of ten cross-sections of seminiferous tubule per bull is adequate for determination of numbers of Sertoli and germ cells. Therefore, the calculation of numbers of Sertoli and germ cells and the ratios presented in this study were based on samples of ten sections selected from different regions of one slide from each bull. These sections were at stages I through VI, as described by Berndtson and Desjardins (1974). When the bull did not have elongate or mature spermatids, the sections chosen were those with the most advanced germ cell type.

Numbers of Sertoli cells, pachytene spermatocytes and round spermatids containing an intact nucleolus were counted in each of the ten sections. These crude counts were converted to true counts according to Abercrombie's formula (Abercrombie, 1946): true counts $=$ (crude counts $\times$ section thickness)/(section thickness + mean nuclear diameter in microns). Section thickness in this case was $5 \mu \mathrm{m}$. On the basis of true counts, the following cell ratios per cross-section were estimated: number of A1 spermatogonia per Sertoli cell (A/S), number of round spermatids per $A 1$ spermatogonium (R/A) and number of round spermatids per Sertoli cell (R/S).

The total number of Sertoli cells per testis (S) was calculated based on the method described by Erickson and Blend (1976). Testicular volume (V) was determined by the formula: $V=$ mass/density (where density $=1.052 \mathrm{~g} \mathrm{~cm}^{-3}$; Johnson and Neaves, 1981). The volume occupied by ten seminiferous tubule cross-sections $\left(V_{\mathrm{st}}\right)$ was calculated by the formula $V_{\text {st }}=\pi \times h \times\left(d^{2} / 4\right)$, where $h$ is the section thickness $(5 \mu \mathrm{m})$ and $d$ is tubule diameter $(\mu \mathrm{m})$. The percentage of testicular volume occupied by seminiferous tubules $\left(\%_{\mathrm{st}}\right)$ was determined as described by Chalkley (1943); briefly, the percentage of 600 'hits' taken at random within a cross-section of a testis. Crude numbers of Sertoli cells per testis were determined by the formula: crude number $=\left(V \times \%_{\mathrm{st}} \times C\right) /\left(V_{\mathrm{st}} \times 10\right)$, where $C$ is the true number of Sertoli cells counted in ten cross-sections. The resulting crude numbers were converted to true counts according to Abercrombie's formula (Abercrombie, 1946): true number $=$ (crude number $\times$ section thickness $) /($ section thickness + average nuclear diameter in microns).

\section{Radioimmunoassays}

Blood samples were collected at the farm and immediately placed on ice. At the laboratory, samples were allowed to warm for $2 \mathrm{~h}$ at room temperature and centrifuged at $1764 \mathrm{~g}$ for $25 \mathrm{~min}$. Serum was harvested and stored at $-20^{\circ} \mathrm{C}$ until assayed for $\mathrm{FSH}, \mathrm{LH}$, testosterone, androstenedione and oestradiol.

Concentrations of FSH were determined in $200 \mu \mathrm{l}$ of serum using a double antibody radioimmunoassay, as described by Bolt and Rollins (1983). Both the first antibody (USDA-5-0122) and the highly purified FSH used for iodination and reference curve (USDA-bFSH-I-1) were provided by D. J. Bolt (USDA, Beltsville, MD). The samples were analysed in two different assays. The detection level of the FSH radioimmunoassay was $0.25 \mathrm{ng} \mathrm{ml}^{-1}$ and the intra- and interassay coefficients of variation were $7 \%$ and $12 \%$, respectively. Peripheral concentrations of $\mathrm{LH}$ were quantified in $100 \mu \mathrm{l}$ of serum using the method first described by Niswender et al. (1969) and modified by Bolt (1981). The LH first antibody (number 15 anti-ovine LH) was obtained from G. Niswender (CSU, Fort Collins, CO) and the purified hormone used for the reference curve and iodination was provided by L. E. Reichert (Rochester Medical School, Albany, NY). The detection level was $31.3 \mathrm{pg} \mathrm{ml}^{-1}$ and the intra- and interassay coefficients of variation were $<9 \%$ and $<12 \%$, respectively.

Samples of serum $(150 \mu \mathrm{l})$ were extracted with $1.5 \mathrm{ml}$ of benzene before being analysed for testosterone, androstenedione and oestradiol. Concentrations of testosterone and androstenedione were estimated based on the single antibody method described by Cox et al. (1987). The androstenedione antibody (X-322 Rao) was purchased from P. N. Rao (Southwest 
Foundation for Biomedical Research, San Antonio, TX) and the testosterone antibody was provided by G. Niswender. The detection level for the testosterone and androstenedione assays were $10 \mathrm{pg} \mathrm{ml}^{-1}$ and $2.5 \mathrm{pg} \mathrm{ml}^{-1}$, respectively. The intraand interassay coefficients of variation were $10 \%$ and $12 \%$, respectively, for the testosterone assay, and $8 \%$ and $12 \%$, respectively, for the androstenedione assay. Concentrations of oestradiol were quantified according to a procedure described by Cox et al. (1987). J. H. Britt (personal communication) modified this assay for bulls mainly by increasing the antibody dilution from approximately 1:800 000 to $1: 1.5$ million and decreasing the amount of serum extracted. The antibody was supplied by N. Manson (Lilly Research Laboratories, Indianapolis, IN). The detection limit of the assay was $0.15 \mathrm{pg}$ $\mathrm{ml}^{-1}$ and the intra- and interassay coefficients of variation were $8 \%$ and $15 \%$, respectively.

Assays were validated by adding known quantities of hormone to previously characterized serum and estimating the recovery. With FSH, $60 \mathrm{pg}, 120 \mathrm{pg}$ and $480 \mathrm{pg}$ were added to $200 \mu \mathrm{l}$ of serum, and $98 \pm 2 \%, 99 \pm 3 \%$ and $95 \pm 5 \%$ were recovered, respectively. With $\mathrm{LH}, 62 \mathrm{pg}, 124 \mathrm{pg}$ and $488 \mathrm{pg}$ were added to $100 \mu \mathrm{l}$ of serum, and in all cases an average of $98 \pm 2 \%$ was recovered. The steroids (androstenedione, testosterone and oestradiol) were added to $150 \mu \mathrm{l}$ of serum and extracted with $1.5 \mathrm{ml}$ of benzene in a multi-vortex unit. Samples were mixed with benzene for $5 \mathrm{~min}$ and left to stand for $5 \mathrm{~min}$, and this process was repeated three times. Of the $5 \mathrm{pg}, 20 \mathrm{pg}$ and $80 \mathrm{pg}$ of androstenedione added, $93 \pm 4 \%$, $97 \pm 5 \%$ and $95 \pm 4 \%$ were recovered, respectively. The same quantities of testosterone were added and recovery was similar to that of androstenedione. With oestradiol, $0.60 \mathrm{pg}, 3.0 \mathrm{pg}$ and $6.0 \mathrm{pg}$ were added, and $99 \pm 3 \%, 92 \pm 3 \%$ and $94 \pm 3 \%$ were recovered, respectively. Values were not corrected for procedural losses.

\section{Statistical analysis}

The effect of exogenous GnRH on peripheral concentrations of FSH, LH, oestradiol, testosterone and androstenedione was evaluated by analysis of variance and Tukey's multipairwise statistical test (SAS, 1990). Within each age period, bodyweight was used as a covariate, if significant. Pearson's partial correlations were used to determine the strength of the linear relationships involving testis size, numbers of Sertoli and germ cells and hormone concentrations (SAS, 1990). Bodyweight was used as the partial variable so that its effect on the correlation between the other variables could be controlled.

\section{Results}

Age-related changes in testis size and basal and GnRH-stimulated peripheral hormone concentrations

Testis diameter and mass at 12 months of age were $59 \pm 2 \mathrm{~mm}$ and $230 \pm 16 \mathrm{~g}$, respectively. The correlation between yearling testis diameter and prepubertal testis diameter was low when diameter was measured before 4 months $(r<0.47, P>0.05)$. However, correlations increased when testis diameter was measured between 5 months and 11 months $(r=0.55, P<0.05$, to $r=0.91, P<0.01)$. Across ages, testis diameter was correlated with bodyweight $(r=0.97$, $P<0.01$ ). When age was held constant, correlations between testis diameter and body weight were high between 4 months and 6 months of age $(r=0.70-0.75, P<0.01)$ but decreased thereafter $(r=0.54, P<0.01$ at 9 months; $r=0.44, P<0.05$ at 12 months). At 12 months of age, testis mass was also correlated with bodyweight $(r=0.56, P<0.01)$, but not with age.

On the basis of Tukey's statistical test ( $\alpha=0.05$ ), concentrations of FSH reached a maximum $3.0 \mathrm{~h}$ after $\mathrm{GnRH}(0.69 \mathrm{ng}$ $\left.\mathrm{ml}^{-1}\right)$ but decreased afterwards $\left(0.52 \mathrm{pg} \mathrm{ml}^{-1}\right.$; Fig. Ia). The response of $\mathrm{LH}$ showed a similar pattern, but the decrease from $21.5 \mathrm{ng} \mathrm{ml}^{-1}$ at $3.0 \mathrm{~h}$ to $8.2 \mathrm{ng} \mathrm{ml}^{-1}$ at $4.5 \mathrm{~h}$ was significant (Fig. Ib). Testosterone increased $1.5 \mathrm{~h}$ after GnRH administration $\left(8.5 \mathrm{ng} \mathrm{ml}^{-1}\right.$; Fig. 1c), but concentrations did not change significantly at $3.0 \mathrm{~h}\left(9.3 \mathrm{ng} \mathrm{ml}{ }^{-1}\right)$ or $4.5 \mathrm{~h}(9.1 \mathrm{ng}$ $\mathrm{ml}^{-1}$ ). In comparison with basal values $\left(3.95 \mathrm{pg} \mathrm{ml}^{-1}\right)$, oestradiol response to $\mathrm{GnRH}$ was significant only at $3.0 \mathrm{~h}(5.3 \mathrm{pg}$ $\left.\mathrm{ml}^{-1}\right)$, but the further increase at $4.5 \mathrm{~h}\left(5.6 \mathrm{pg} \mathrm{ml}^{-1}\right)$ was minimal (Fig. Id). Androstenedione increased $(P<0.05)$ from $262 \pm 47 \mathrm{pg} \mathrm{ml}^{-1}$ at basal to $332 \pm 39 \mathrm{pg} \mathrm{ml}^{-1}$ and $40 \mathrm{I} \pm 47 \mathrm{pg} \mathrm{ml}^{-1}$ at $1.5 \mathrm{~h}$ and $3.0 \mathrm{~h}$ after GnRH administration, respectively, but the increase to $408 \pm 19 \mathrm{pg} \mathrm{ml}^{-1}$ at $4.5 \mathrm{~h}$ was not different from the values at $1.5 \mathrm{~h}$ and $3.0 \mathrm{~h}$ (data not shown)

Basal FSH decreased from $0.45 \pm 0.05 \mathrm{ng} \mathrm{ml}^{-1}$ at 2 months to $0.36 \pm 0.01 \mathrm{ng} \mathrm{ml}^{-1}$ at 5 months $(P<0.05$; Fig. 1a), but increased again at 10 months and 12 months $(0.44 \pm 0.04 \mathrm{ng}$ $\left.\mathrm{ml}^{-1}, P<0.05\right)$. At all ages, concentrations of FSH increased significantly $(P<0.05)$ both $1.5 \mathrm{~h}$ and $3.0 \mathrm{~h}$ after $\mathrm{GnRH}$ administration. Basal and GnRH-stimulated FSH concentrations were correlated $(r=0.79-0.90, P<0.01)$ within and across ages.

Between 2 months and 4 months of age, LH concentrations increased from $0.47 \pm 0.03 \mathrm{ng} \mathrm{ml}^{-1}$ to $0.66 \pm 0.06 \mathrm{ng} \mathrm{ml}^{-1}$ $(P<0.05)$, but remained almost unchanged until 6 months of age (Fig. 1b). Basal LH increased to $1.09 \pm 0.05 \mathrm{ng} \mathrm{ml}^{-1}$ $(P<0.05)$ at 9 months, but further increases were not significantly different from the values at 9 months $(P>0.05)$. The average increase in $\mathrm{LH}$ response to $\mathrm{GnRH}$ was $27 \pm 2$-fold and $35 \pm 2$-fold at $1.5 \mathrm{~h}$ and $3.0 \mathrm{~h}$, respectively. Basal and GnRHstimulated LH concentrations were not correlated $(P>0.05)$ within age periods. Across all ages, basal and $\mathrm{GnRH}$-stimulated LH concentrations were correlated $(r=0.65, P<0.01)$ and concentrations of $\mathrm{LH}$ at $1.5 \mathrm{~h}$ were correlated with both basal FSH $(r=0.48, P<0.05)$ and FSH concentrations at $1.5 \mathrm{~h}$ $(r=0.69, P<0.01)$. In addition, $\mathrm{LH}$ concentration at $3.0 \mathrm{~h}$ was related to FSH concentration at $3.0 \mathrm{~h}(r=0.75, P<0.01)$.

Basal concentrations of testosterone increased from $0.10 \pm 0.01 \mathrm{ng} \mathrm{ml}^{-1}$ at 2 months to $6.5 \pm 0.06 \mathrm{ng} \mathrm{ml}^{-1}$ at 10 months, but decreased to $5.0 \pm 0.85 \mathrm{ng} \mathrm{ml}^{-1}$ at 12 months. $\mathrm{GnRH}$ injections caused significant $(P<0.05)$ increases in testosterone at all ages (Fig. 2a). Basal and GnRH-stimulated testosterone were correlated within ages $(r=0.48-0.56$, $P<0.05)$ and across ages $(r=0.53-0.81, P<0.05)$. The highest concentrations of basal androstenedione in serum were detected at 3 months $\left(393 \pm 41 \mathrm{pg} \mathrm{ml}^{-1}\right)$ and 4 months $\left(401 \pm 50 \mathrm{pg} \mathrm{ml}^{-1}\right.$; Fig $2 \mathrm{~b}$ ). In addition, basal androstenedione increased from $171 \pm 16 \mathrm{pg} \mathrm{ml}^{-1}$ at 6 months to $342 \pm 26 \mathrm{pg}$ $\mathrm{ml}^{-1}$ at 10 months $(P<0.05)$, but declined to $270 \pm 17 \mathrm{pg}$ $\mathrm{ml}^{-1}$ at 12 months $(P<0.05)$. Androstenedione response to 
exogenous GnRH was also significant at all ages $(P<0.05)$. Within ages, basal and $\mathrm{GnRH}$-stimulated androstenedione were correlated (average $r=0.78, P<0.01$ ). Also, within ages, basal
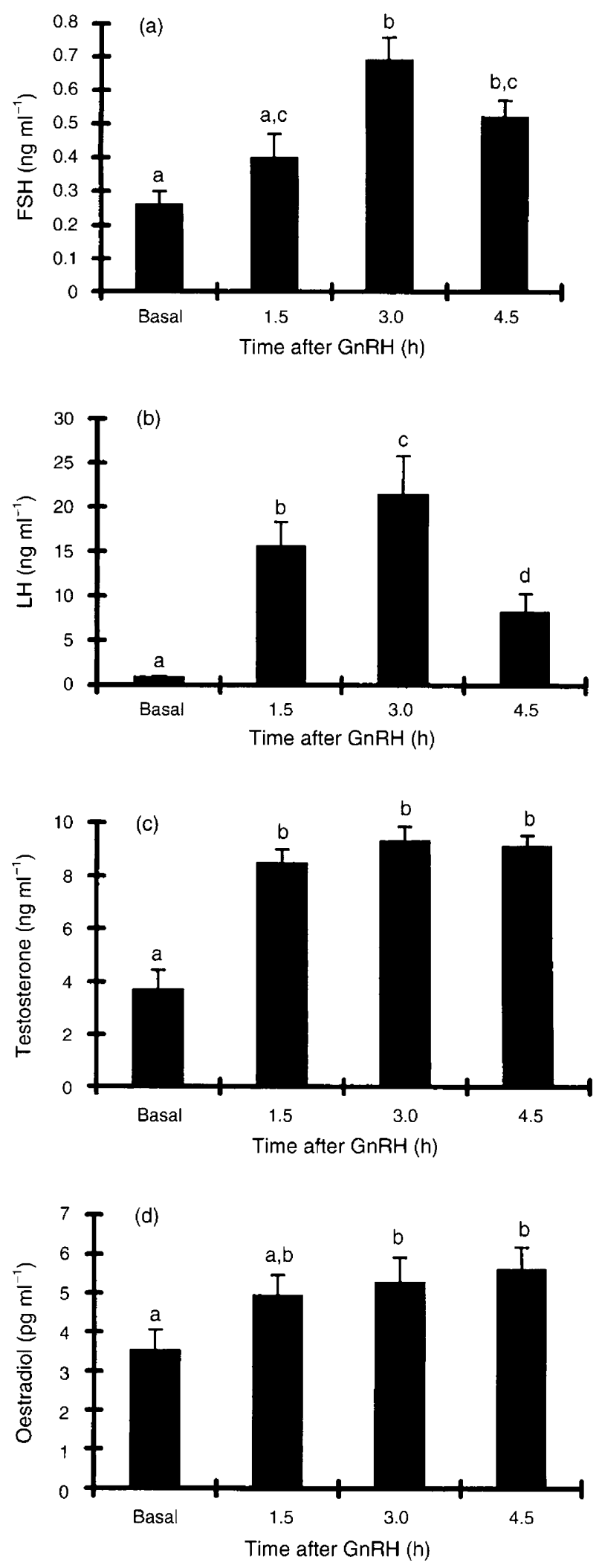

concentrations of androstenedione and testosterone were correlated with each other $(r=0.48-0.71, P<0.05)$ and with LH $(r=0.47-0.60, P<0.05)$.

Basal oestradiol increased $(P<0.05)$ from $2.58 \pm 0.11 \mathrm{pg}$ $\mathrm{ml}^{-1}$ at 2 months to $3.71 \pm 0.31 \mathrm{pg} \mathrm{ml}^{-1}$ at 3 months $(P<0.05$; Fig. 2 c). Oestradiol concentrations increased again $(P<0.05)$ from $3.70 \pm 0.22 \mathrm{pg} \mathrm{m}^{-1}$ at 8 months to $9.91 \pm 0.7 \mathrm{pg} \mathrm{ml}^{-1}$ at 12 months. Concentrations of oestradiol increased $(P<0.05)$ in response to $\mathrm{GnRH}$ at all ages. Within all age periods, basal and GnRH-stimulated oestradiol were correlated (average $r=0.63, P<0.01$ ) and positive correlations were found between basal and GnRH-stimulated oestradiol and testosterone concentrations $(r=0.54$ at 4 months, $P<0.05$; $r=0.46 \cdots 0.81$ between 6 and 12 months of age; $P<0.05$ ).

Correlations between testis size, number of Sertoli cells and quantitative aspects of spermatogenesis in the yearling testis

The mean number of Sertoli cells per testis was $4.6 \pm 0.3 \times 10^{9}$. In addition, there were $6.3 \pm 1.4$ round spermatids and 0.10 A1 spermatogonia per Sertoli cell, and $42.2 \pm 9.5$ round spermatids per A1 spermatogonium in the seminiferous tubules. Of the seminiferous tubule sections, $21 \pm 7 \%$ were without germ cells, and $32 \pm 3 \%$ of the sections had round spermatids as the most advanced germ cell type. There was also great variability in other histological criteria of the yearling testis. Nine bulls had $>50 \%$ of the seminiferous tubule sections with either elongate or mature spermatids, while one bull had no germ cells, and two other bulls had tubules with spermatogonia and spermatocytes, but no spermatids.

Testis mass was correlated with number of Sertoli cells per testis in yearling Angus bulls ( $r=0.85, P<0.01$; Table 1$)$. In addition, bulls with heavier testes had more round spermatids generated per AI spermatogonium $(r=0.73, P<0.01)$ and more AI spermatogonia $(r=0.54, P<0.05)$ and round spermatids $(r=0.69, P<0.01)$ supported by each Sertoli cell. Also, larger populations of Sertoli cells per testis were associated with higher numbers of round spermatids per A1 spermatogonium $(r=0.62, P<0.01)$. Correlations between testis diameter, Sertoli cells and cell ratios per seminiferous tubule section were also significant $(r=0.57, P<0.05$ to $r=0.84$, $P<0.01$; Table 1).

\section{Correlations between peripheral hormone concentrations and} yearling testis size, number of Sertoli cells and quantitative aspects of spermatogenesis

Yearling testis diameter was related to peripheral concentrations of GnRH-stimulated testosterone measured at 3

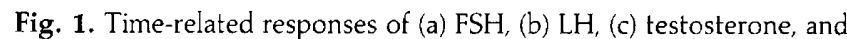
(d) oestradiol to GnRH in Angus bulls at the age of 8 months $(244.4 \pm 3.7 \mathrm{~kg})$. Animals $(n=8)$ were injected with a single dose of $\mathrm{GnRH}$ (des-Gly ${ }^{10},\left[\mathrm{D}-\mathrm{Ala}{ }^{6}\right]-\mathrm{GnRH}$-ethylamide) and blood samples were taken $0,1.5,3.0$ and $4.5 \mathrm{~h}$ later. Samples obtained at time 0 represent basal concentrations. Error bars represent SD of means. ${ }^{a b}$ Different superscripts represent significant differences according to Tukey's statistical test $(p<0.05)$. 

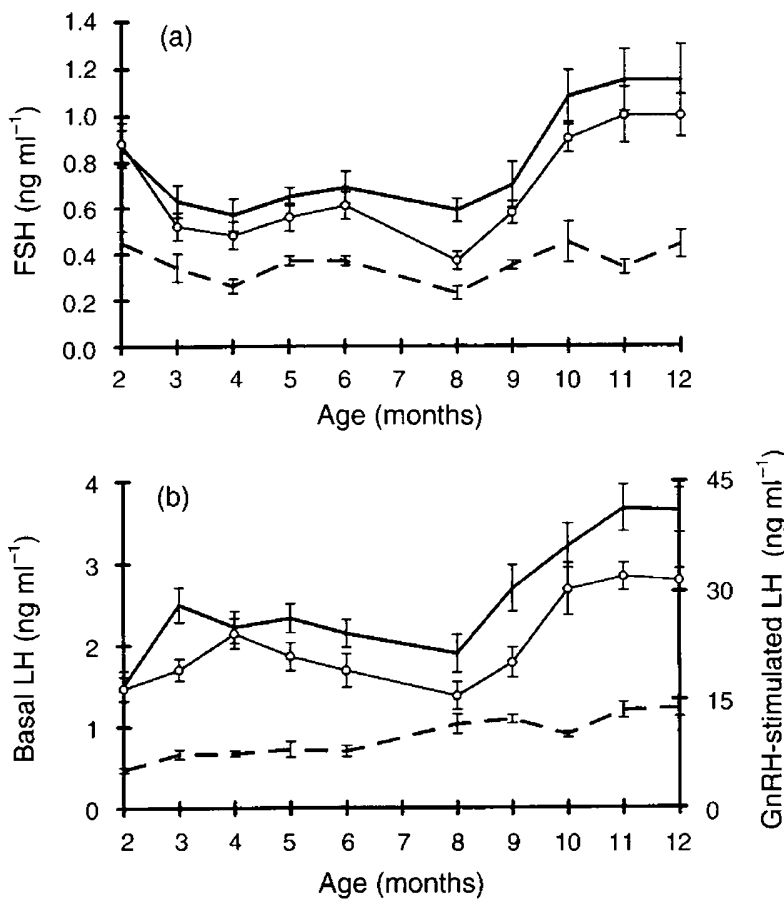

Fig. 2. Age-related changes in peripheral concentrations of basal and GnRH-stimulated (a) FSH and (b) LH in Angus bulls. Basal values represent the average of three basal samples taken at $1.5 \mathrm{~h}$ intervals $(---)$. GnRH-stimulated concentrations represent samples taken $1.5 \mathrm{~h}(\mathrm{O})$ and $3.0 \mathrm{~h}(\longrightarrow)$ after GnRH. Error bars represent SD of the means within age periods $(n=24)$.

months of age $(r=0.48, P<0.05)$. There were inverse relationships between testis diameter and basal concentrations of FSH measured from 2 months $(r=-0.67, P<0.01)$ to 12 months of age $(r=-0.74, P<0.01$; Table 2$)$. In addition, there were no significant differences in $r$ values between basal and GnRH-stimulated concentrations of FSH when either testis mass (average $r=-0.53$ and -0.52 , respectively) or testis diameter (average $r=-0.64$ and -0.59 , respectively) was used in the calculations. Testis diameter at 12 months of age was not meaningfully correlated with concentrations of $\mathrm{LH}$, androstenedione and oestradiol measured from 2 months to 12 months of age $(P>0.05)$.

Correlations between number of Sertoli cells and basal FSH were significant when FSH was measured at 2 months $(r=-0.51, P<0.05)$ and 3 months $(r=-0.54, P<0.05)$, as well as from 8 months $(r=-0.47, P<0.05)$ to 12 months of age $(r=-0.53, P<0.01$; Table 2$)$. Numbers of round spermatids per A1 spermatogonium in the yearling testis were correlated with basal concentrations of FSH at 3 months $(r=-0.57, P<0.05)$ and from 8 months $(r=-0.49, P<0.05)$ to 12 months $(r=-0.52, P<0.01)$. Numbers of round spermatids per Sertoli cell were also correlated with basal FSH at 3 months $(r=-0.50, P<0.05)$ and FSH concentrations measured from 9 months $(r=-0.56, P<0.05)$ to 12 months $(r=-0.59, P<0.01)$. GnRH-stimulated FSH was also related to number of Sertoli cells, number of round spermatids per AI spermatogonium and number of round spermatids per Sertoli cell at the same ages $(r=-0.48, P<0.05$ to $r=-0.61$, $P<0.01$ )

\section{Discussion}

Testis diameter before 4 months of age was not a reliable indicator of yearling testis size but measurements taken after 5 months were more closely associated with testis diameter at 12 months of age. Active spermatogenesis has not begun before 4 months (Curtis and Amann, 1981) and this may be required to accentuate differences between animals. Correlations between testis size and bodyweight decreased with age but they were still significant at 12 months $(r=0.56)$. Studies have shown correlations between testis size and body weight in pre- and postpubertal rams $(r=0.69$; Yarney et al., 1990) and in bulls $(r=0.30$ to 0.55 ; Amann, 1970). In addition, Lunstra et al. (1978) found that bodyweight was related to scrotal circumference $(r=0.73)$ in yearling beef bulls. Thus, there appears to be a certain degree of association between body weight and testis size in young bulls.

Time-related responses to exogenous $\mathrm{GnRH}$ revealed that hormone concentrations at $4.5 \mathrm{~h}$ were either lower (FSH, LH, testosterone) than those measured at $3.0 \mathrm{~h}$ or the increase was minimal and not significant (oestradiol). Therefore, it was decided that blood samples collected at $1.5 \mathrm{~h}$ and $3.0 \mathrm{~h}$ would provide sufficient information about peak responses of gonadotrophins and steroids to GnRH. Moreover, a third sample taken at $4.5 \mathrm{~h}$ would cause unnecessary stress to the animals.

Concentrations of FSH were high at 2 months, low at 4 months and increased again at 5 months and 6 months of age in Angus bulls, a pattern similar to that one described by MacDonald et al. (1990) in Holstein bulls. Within and across ages, there were high correlations between basal and GnRHstimulated FSH concentrations, even when only one blood sample was used to estimate basal hormone concentrations (data not shown). Thus, peripheral FSH measured $1.5 \mathrm{~h}$ and $3.0 \mathrm{~h}$ after a GnRH challenge is a reliable indicator of age-related changes in basal secretion in young bulls.

Basal LH showed an initial increase at 2 months and a second increase after 6 months, which is in agreement with studies performed by Rawlings et al. (1978) and Evans et al. (1993). The response of LH to GnRH was always greater than that of FSH, in accordance with the fact that LH is more dependent on GnRH activity than is FSH (Price, 1991). Across ages, patterns of GnRH-stimulated LH resembled those of basal $\mathrm{LH}$, with the highest concentrations being detected at 2 months and after 8 months. However, in contrast to FSH, within-age correlations between basal and GnRH-stimulated LH were not significant. These results are possibly related to the fact that much of the FSH that is synthesized is secreted while storage of $\mathrm{LH}$ in the gonadotrophs is much greater than the amount that is secreted basally (Price, 1991). Lack of correlation between the response of $\mathrm{LH}$ to $\mathrm{GnRH}$ and basal concentrations reflects the differences between basal secretion and storage of LH in the gonadotrophs.

Age-related changes in basal testosterone paralleled those of LH. These results are similar to those of Evans et al. (1995), which showed that the highest concentrations of testosterone occurred after the age of 9 months in Hereford bulls. The difference between basal and GnRH-stimulated concentrations of testosterone increased with age, probably as a consequence of maturation of the Leydig cells (Wrobel, 1990). The highest 
Table 1. Pearson's partial correlations between testis mass and diameter, number of Sertoli cells per testis and cell ratios per seminiferous tubule sections in yearling Angus bulls $(n=24)$

\begin{tabular}{|c|c|c|c|c|c|}
\hline \multirow[b]{2}{*}{ Variable } & \multirow{2}{*}{$\begin{array}{l}\text { Testis } \\
\text { mass }\end{array}$} & \multirow{2}{*}{$\begin{array}{c}\text { Testis } \\
\text { diameter }\end{array}$} & \multicolumn{3}{|c|}{ Cell ratios } \\
\hline & & & $\mathrm{R} / \mathrm{A}^{*}$ & $R / S^{\dagger}$ & $A / S^{\ddagger}$ \\
\hline Sertoli cells per testis & $0.85^{\mathrm{b}}$ & $0.84^{\mathrm{b}}$ & $0.62^{b}$ & NS & NS \\
\hline$R / A^{*}$ & $0.73^{\mathrm{b}}$ & $0.69^{b}$ & - & $0.83^{\mathrm{b}}$ & $0.49^{\mathrm{a}}$ \\
\hline$R / S^{\dagger}$ & $0.69^{\mathrm{b}}$ & $0.73^{\mathrm{b}}$ & - & - & $0.85^{\mathrm{b}}$ \\
\hline $\mathrm{A} / \mathrm{S}^{\dagger}$ & $0.54^{\mathrm{a}}$ & $0.57^{\mathrm{a}}$ & - & - & - \\
\hline
\end{tabular}

${ }^{*} \mathrm{R} / \mathrm{A}=$ number of round spermatids per $\mathrm{A} 1$ spermatogonium; ${ }^{\dagger} \mathrm{R} / \mathrm{S}=$ number of round spermatids per Sertoli cell; ${ }^{\ddagger} \mathrm{A} / \mathrm{S}=$ number A1 spermatogonia per Sertoli cell.

Partial variable: bodyweight at the age of 12 months.

NS, nonsignificant $(P>0.05) ;{ }^{\circ} P<0.05 ;{ }^{b} P<0.01$.

Table 2. Pearson's partial correlations between peripheral concentrations of basal FSH measured from 2 months to 12 months and testis diameter, number of Sertoli cells per testis, number of round spermatids per Sertoli cell $(R / S)$ and number of round spermatids per A1 spermatogonium (R/A) in yearling Angus bulls $(n=24)$

Age at which basal concentrations of FSH were quantified (months)

\begin{tabular}{lccccccccccc}
\cline { 2 - 9 } & 2 & 3 & 4 & 5 & 6 & 8 & 9 & 10 & 11 & 12 \\
\hline Testis diameter & $-0.53^{\mathrm{b}}$ & $-0.70^{\mathrm{b}}$ & $-0.60^{\mathrm{b}}$ & $-0.55^{\mathrm{b}}$ & $-0.59^{\mathrm{b}}$ & $-0.63^{\mathrm{b}}$ & $-0.53^{\mathrm{b}}$ & $-0.73^{\mathrm{b}}$ & $-0.70^{\mathrm{b}}$ & $-0.74^{\mathrm{b}}$ \\
Sertoli cells per testis & $-0.51^{\mathrm{a}}$ & $-0.54^{\mathrm{a}}$ & NS & NS & NS & $-0.47^{\mathrm{a}}$ & $-0.50^{\mathrm{a}}$ & $-0.48^{\mathrm{a}}$ & $-0.51^{\mathrm{a}}$ & $-0.53^{\mathrm{a}}$ \\
R/S & NS & $-0.57^{\mathrm{a}}$ & NS & NS & NS & $-0.49^{\mathrm{a}}$ & $-0.55^{\mathrm{a}}$ & $-0.60^{\mathrm{b}}$ & $-0.52^{\mathrm{a}}$ & $-0.52^{\mathrm{a}}$ \\
R/A & NS & $-0.50^{\mathrm{a}}$ & NS & NS & NS & NS & $-0.56^{\mathrm{a}}$ & $-0.64^{\mathrm{b}}$ & $-0.56^{\mathrm{a}}$ & $-0.59^{\mathrm{b}}$ \\
\hline
\end{tabular}

For each age, bodyweight was used as a partial variable.

NS, nonsignificant $(P>005)$; ${ }^{a} P<0.05 ;{ }^{b} P<0.01$.

Basal concentration of FSH represents the average of three blood samples taken at $1.5 \mathrm{~h}$ intervals.

concentrations of androstenedione were detected when bulls were 3-4 months old, in accordance with the findings of Malak and Thibier (1979). However, it had not been shown previously that a second increase in androstenedione occurs between 8 months and 10 months of age, coinciding with increases in testosterone, FSH and LH.

Basal oestradiol in Angus bulls showed a moderate increase between 2 months and 8 months of age, but a sharp increase after 8 months, reaching nearly $10 \mathrm{pg} \mathrm{ml}^{-1}$ at the age of 12 months. Evans et al. (1993) described a similar pattern in

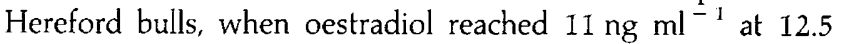
months of age. Basal and GnRH-stimulated concentrations of oestradiol, as well as those of androstenedione and testosterone, were correlated at all ages, suggesting that, as observed for $\mathrm{FSH}$ but not for $\mathrm{LH}$, the basal secretory activity of the testes closely reflects its secretory pattern when stimulated by GnRH-induced FSH and LH.

The average number of Sertoli cells per testis estimated in Angus bulls $\left(4.59 \pm 0.32 \times 10^{9}\right)$ was similar to that found in Holstein $\left(4-13 \times 10^{9}\right.$ per testis; Berndtson et al., 1987a), Hereford and Angus bulls (3-11.5 $\times 10^{9}$; Berndtson et al., $1987 \mathrm{~b}$ ). In addition, there were averages of 6.3 spermatids per Sertoli cell and 42 spermatids per A1 spermatogonium in cross-sections of the yearling testis. Berndtson et al. (1987a, b) found 4-12 spermatids per Sertoli cell and 18-46 spermatids per AI spermatogonium in mature Holstein bulls. Erickson and
Blend (1976) found a close relationship between number of Sertoli cells and testis size in rats by showing that irradiationinduced loss of Sertoli cells caused an irreversible decrease in testis mass and sperm-producing capacity. Berndtson et al. (1987a, b) showed positive correlations between number of Sertoli cells and testis size and daily sperm production in bulls. In the present study, testis mass was not only determined by the Sertoli cell population but also by the ability of Sertoli cells to support the development of AI spermatogonia and spermatids. Large testes had low rates of germ cell degeneration, as evidenced by the ratio of spermatids to type AI spermatogonia. The association between the spermatid:AI ratio and number of Sertoli cells per testis $(r=0.62)$ indicates that germ cell degeneration in the testis is at least in part controlled by the Sertoli cells. As might be expected, more AI spermatogonia supported by Sertoli cells allowed a larger number of spermatids per Sertoli cell $(r=0.85)$, and this association was determined partially by the low rate of spermatid degeneration $(r=0.49)$. It appears that when germ cell degeneration is low, there are more spermatids associated with each Sertoli cell. Positive correlations were observed between spermatid:type AI and spermatid:Sertoli cell ratios. These results support the hypothesis that the increase in number of germ cells per Sertoli cell is not followed by an increase in the rate of germ cell degeneration (Berndtson et al., 1987a). In the present study, the correlation between number of round 

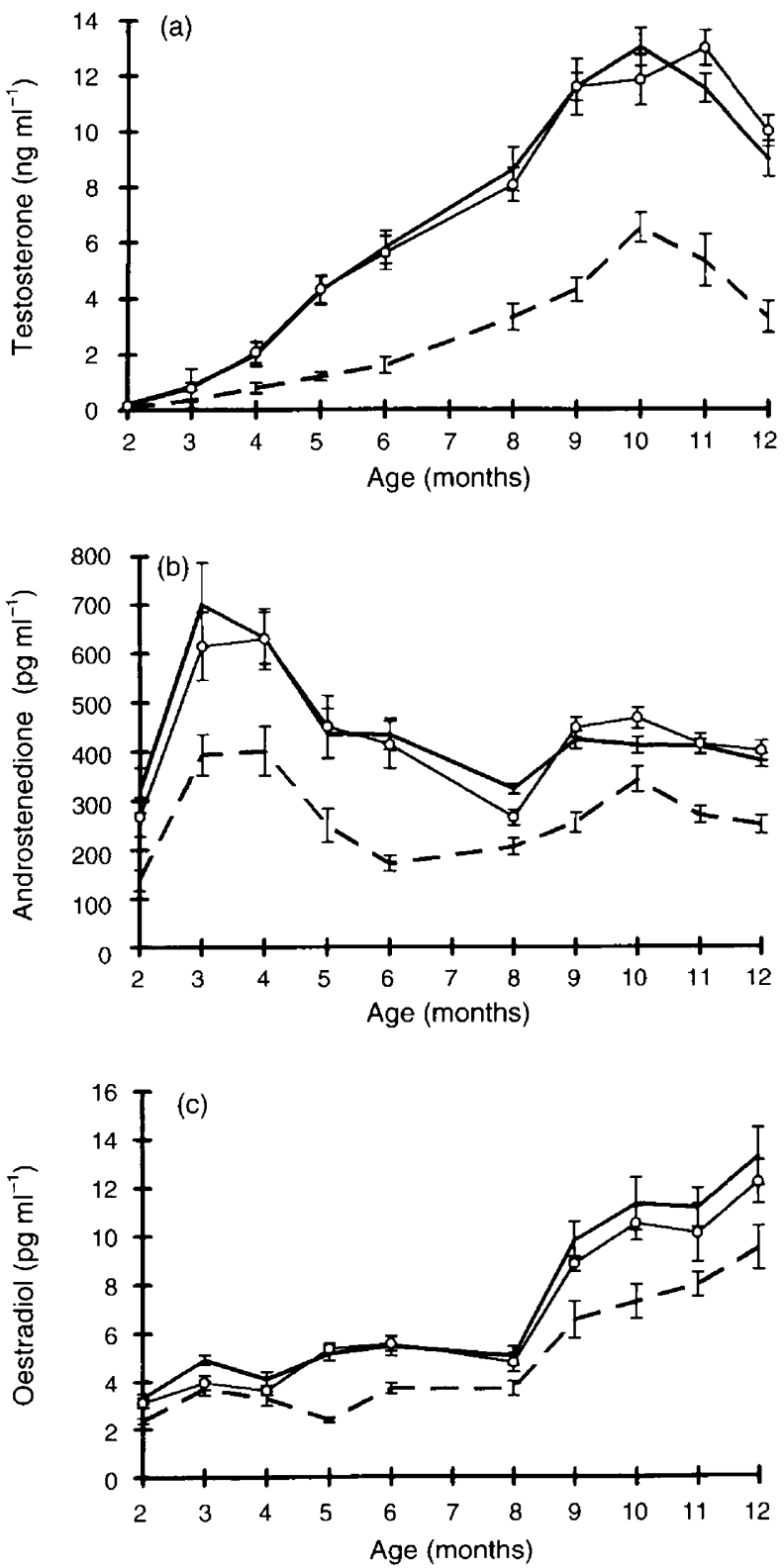

Fig. 3. Age-related changes in peripheral concentrations of basal and GnRH-stimulated (a) testosterone, (b) androstenedione, and (c) oestradiol in Angus bulls. Basal values represent the average of three basal samples taken at $1.5 \mathrm{~h}$ intervals $(---)$. GnRH-stimulated concentrations represent samples taken $1.5 \mathrm{~h}(\mathrm{O})$ and $3.0 \mathrm{~h} \mathrm{(}(-)$ after GnRH. Error bars represent SD of the means within age periods $(n=24)$.

spermatids per Sertoli cell and total number of Sertoli cell per testis was low $(r=0.43, P=0.07)$, while Berndtson et al. (1987a, b) found negative correlations between these variables $(r=-0.40)$. The reason for these differences is probably related to the fact that Berndtson et al. used older bulls (> 1.5 years).

The results of the present study are the first to show that basal FSH measured between 2 months and 12 months of age was not only negatively related to yearling testis size but also to number of Sertoli cells, yield of germ cells per Sertoli cell and rate of germ cell degeneration. Other studies have reported similar results, but only in adult bulls. Swanson $e t$ al. (1971) observed that the pituitary content of FSH in 12-monthold Hereford bulls was negatively correlated with number of epididymal spermatozoa. In addition, Schanbacher (1990) reported that, within a group of bulls that had been immunized against inhibin, FSH was inversely related to testis mass $(r=-0.70)$ at the age of 13 months.

Although exogenous $\mathrm{GnRH}$ caused significant increases in FSH secretion at all ages, it seems that the GnRH treatment did not provide additional information about the degree of association between FSH and testis criteria. However, in the case of testosterone, GnRH challenges were necessary to detect correlations with testis size. Malak and Thibier (1985) also found negative correlations between GnRH-stimulated FSH and sperm output and quality in yearling bulls $(r=-0.40$ to -0.70 ), but only when the FSH response was amplified by a pretreatment with dexamethasone. These correlations are similar to the values described in the present study where FSH at 12 months of age increased from $0.44 \mathrm{ng} \mathrm{ml}^{-1}$ (basal) to $0.95 \mathrm{ng} \mathrm{ml}^{-1}$ and $1.1 \mathrm{ng} \mathrm{ml}^{-1}$ at 1.5 and $3.0 \mathrm{~h}$ after $\mathrm{GnRH}$, respectively. This represented increases of 2.15 - and 2.5 -fold. According to Malak and Thibier (1985), FSH concentration increased from $1.6 \mathrm{ng} \mathrm{ml}^{-1}$ to a maximum of $2.6 \mathrm{ng} \mathrm{ml}-1$ after GnRH only (1.6-fold) and to $4.0 \mathrm{ng} \mathrm{ml}^{-1}$ (2.5-fold) after $\mathrm{GnRH}$ plus dexamethasone. Thus, the results presented here with GnRH only were similar to the response achieved with GnRH plus dexamethasone, in terms of both magnitude of FSH secretion and correlations with testis criteria. The reason a high FSH response was obtained with GnRH only is probably a consequence of the dose of GnRH agonist used. However, it remains to be determined whether the FSH secretion stimulated by a GnRH agonist combined with dexamethasone could improve the significance of the correlations with testis size and histology.

The reason for the negative correlations between FSH and testis criteria is not known but it can be hypothesized that heavier testes secrete higher concentrations of steroids, which in turn control the synthesis and secretion of gonadotrophins and $\mathrm{GnRH}$ and promote the activity of the Sertoli and Leydig cells. In this regard, the results of the present study showed that concentrations of testosterone at 3 months were positively correlated with yearling testis size, although the $r$ value was low $(r=0.48)$. In addition, because inhibin regulates the secretion of FSH (Tilbrook et al., 1993) and there is an inverse relationship between these two hormones in bulls after the age of 10 weeks (MacDonald $e t$ al., 1990), it is possible that bulls with heavier testes at 12 months of age secreted more inhibin throughout the prepubertal phase of development. The fact that FSH accounted for only part of the variation in testis size suggests that other systemic or intratesticular hormones or growth factors may also play crucial roles in determining the number of Sertoli and germ cells in bulls.

The authors thank N. R. Rohrbach for her assistance with the radioimmunoassays and the staff of the Knoxville Experimental Station for their care and handling of the animals. They also thank A. Saxton, of the Department of Animal Science, for his assistance with the statistical analysis. 


\section{References}

Abercrombie M (1946) Estimation of nuclear population from microtome sections Anatomical Record 94 239-247

Amann RP (1962) Reproductive capacity of dairy bulls IIl. The effect of ejaculation frequency, unilateral vasectomy, and age on spermatogenesis American Journal of Anatomy 110 49-68

Amann RP (1970) Sperm production rates. In The Testis Vol. I pp 433-482 Eds AD Johnson, WR Gomes and NL Vandemark. Academic Press, New York

Amann RP and Almquist JO (1962) Reproductive capacity of dairy bulls VIII. Direct and indirect measurements of testicular sperm production Journal of Dairy Science 45 774-781

Bardin CW, Cheng CY, Mustow NA and Gunsalus GL (1994) The Sertoli cell. In The Physiology of Reproduction 2nd Edn pp 1291-1331 Eds E Knobil and ID Neil. Raven Press, New York

Berndtson WE and Desjardins C (1974) The cycle of the seminiferous epithelium and spermatogenesis in the bovine testis American Joumal of Anatomy 140 $167-180$

Berndtson WE, Igboeli G and Parker WG (1987a) The numbers of Sertoli cells in mature Holstein bulls and their relationship to quantitative aspects of spermatogenesis Biology of Reproduction 37 60-67

Berndtson WE, Igboeli G and Pickett BW (1987b) Relationship of absolute numbers of Sertoli cells to testicular size and spermatogenesis in young beef bulls Journal of Animal Science 64 241-246

Bolt DJ (1981) Development of homologous radioimmunoassay for ovine follicle stimulating hormone: studies of estrus, ovariectomy, oestradiol and releasing hormone Journal of Animal Science 53 730-741

Bolt DJ and Rollins R (1983) Development and application of a radioimmunoassay for bovine follicle stimulating hormone Journal of Animal Science $\mathbf{5 6}$ 146-154

Chalkley HW (1943) Method for the quantitative morphologic analysis of tissue Journal of the National Cancer Institute 4 47-53

Coulter GH and Foote RH (1979) Bovine testicular measurements as indicators of reproductive performance and their relationship to productive traits in cattle: a review Theriogenology 11 297-308

Cox NM, Ramirez JL, Matamoros IA, Bennett WA and Britt JH (1987) Influence of season on estrous and luteinizing hormone responses to oestradiol benzoate in ovariectomized sows Theriogenology 27 395-407

Curtis SK and Amann RP (1981) Testicular development and establishment of spermatogenesis in Holstein bulls Journal of Animal Science 53 1645-1657

Erickson BH and Blend WJ (1976) Response of the Sertoli cell and stem cell to ${ }^{60} \mathrm{Co} \gamma$-radiation (dose and dose rate) in testes of immature rats Biology of Reproduction 14 641-650

Evans ACO, Currie WD and Rawlings NC (1993) Opioidergic regulation of gonadotrophin secretion in the early prepubertal bull calf joumal of Reproduction and Fertility 99 45-51

Evans ACO, Davies FJ, Nasser LF, Bowman and Rawlings NC (1995) Differences in early patterns of gonadotrophin secretion between early and late maturing bulls, and changes in semen characteristics at puberty Theriogenology $43569-578$

Johnson L and Neaves WB (1981) Age-related changes in the Leydig cell population, seminiferous tubules, and sperm production in stallions Biology of Reproduction 24 703-712

Khan SA, Teerds K and Dorrington J (1994) Regulation of DNA synthesis in Leydig cells. In Function of Somatic Cells in the Testis pp 151-170 Ed. A Bartke. Springer-Verlag, New York

Lunstra DD, Ford JJ and Echternkamp SE (1978) Puberty in beef bulls: hormone concentrations, growth, testicular development, sperm production and sexual aggressiveness in bulls of different breeds Journal of Animal Science $\mathbf{4 6}$ 1054-1062

Lunstra DD, Gregory KE and Cundiff LV (1988) Heritability estimates and adjustment factors for the effects of bull age and age of dam on yearling testicular size in breeds of bulls Theriogenology 30 127-136

MacDonald RD, Deaver DR and Schanbacher BD (1990) Prepubertal changes in plasma FSH and inhibin in Holstein bull calves: responses to castration and (or) oestradiol Journal of Animal Science 69 276-282

Malak GA and Thibier M (1979) Peripheral plasma androstenedione and testosterone concentrations in bulls before and during puberty journal of Reproduction and Fertility 56 7-10

Malak GA and Thibier M (I985) Individual variations in FSH release after a $\mathrm{GnRH}$ challenge and relationship with semen output in young bulls journal of Reproduction and Fertility 75 345-350

Martin LC, Brinks JC, Bourdon RM and Cundiff LV (1992) Genetic effects on beef heifer puberty and subsequent reproduction Journal of Animal Science $\mathbf{7 0}$ 4006-4017

Niswender GD, Richert Jr LE, Midgley AR, and Nalbandov AV (1969) Radioimmunoassay for bovine and ovine luteinizing hormone Endocrinology $\mathbf{8 4}$ 1166-1173

Orth JM, Gunsalus GM and Lamperti AA (1988) Evidence from Sertoli celldepleted rats indicates that spermatids numbers in adults depends on Sertoli cells produced during perinatal development Endocrinology 122 787-794

Palasz AT, Cates WF, Barth AD and Mapletoft RJ (1994) The relationship between scrotal circumference and quantitative testicular traits in yearling beef bulls Theriogenology 42 715-726

Price CA (1991) The control of FSH in the large domestic species Journal of Endocrinology 131 1.77-184

Rawlings NC, Fletcher PW, Henricks DM and Hill JR (1978) Plasma luteinizing hormone (LH) and testosterone levels during sexual maturation in beef bul calves Biology of Reproduction 19 1108-1112

SAS Institute Inc. (1989) SAS/STAT " User's Guide, Version 6, 4th Edn, Vol. 2 p 846. SAS Institute Inc., Cary, NC

Schanbacher BD (1982) Hormonal interrelationships between hypothalamus, pituitary and testis of rams and bulls Journal of Animal Science 55 (Supplement 2) 56-67

Schanbacher BD (1990) Pituitary and testicular responses of beef bulls to active immunization against inhibin alpha Journal of Animal Science 69 252-257

Sharpe RM (1994) Regulation of spermatogenesis. In The Physiology of Reproduction 2nd Edn pp 1363-1434 Eds E Knobil and JD Neil. Raven Press, New York

Swierstra EE (1966) Structural composition of Shorthorn bull testes and daily spermatozoa production as determined by quantitative testicular histology Canadian Journal of Animal Science 46 107-118

Swanson LV, Wettemann RP, Rawlings RP, Rafs HD and Magee WT (1971) Pubertal relationships of some endocrine and reproductive criteria in Hereford bulls Journal of Animal Science 33 823-828

Tilbrook AJ, De Kretser DM and Clarke IJ (1993) Human recombinant Inhibin A suppress plasma follicle-stimulating hormone to intact levels but has no effect on luteinizing hormone in castrated rams Biology of Reproduction 49 $779-788$

Wrobel KH (1990) The postnatal development of the bovine Leydig cell population Reproduction in Domestic Animals 25 51-60

Yarney TA, Sanford LM and Palmer WM (1990) Pubertal development of ram lambs: body weight and testicular measurements as indices of postpubertal reproductive function Canadian Journal of Animal Science 70 139-147 